\title{
Paranoia and Multiple Personalities In Postmodern Fiction
}

\author{
Lect. Nurten ŞEN
}

May God us keep

From Single vision \& Newton's sleep.

—William Blake

\begin{abstract}
Postmodernism is a movement which starts in the second half of the twentieth century and continues onwards. The only thing one can precisely say about postmodernism is that it represents a radical break from Modernism. Postmodernism has changed the cultural atmosphere radically. Lyotard in his book entitled The Postmodern Condition: A Report on Knowledge posits that "[Postmodernism] designates the state of our culture following the transformations, which, since the end of the nineteenth century, have altered the game rules for science, literature and the arts" (1979, p.9). As is implied, whilst in Modernism, there were strict boundaries between high and low art forms, in Postmodernism such binaries are questioned. In Modernism, truth and knowledge are based on scientific facts; so, there is the singularity and absolute precision of truth. However, with the Postmodernist movement, the plurality of truth has been become the widespread notion. It may be suggested that this phenomenon takes us to the sphere of paranoia. Namely, in the Postmodern era, the form of thinking represents a radical break from the previous movements and this occurrence causes paranoia. Considering all the changes in regard with the perception of reality in the Postmodern age, this paper will analyse certain elements that trigger paranoia and the
\end{abstract}

1 Istanbul Aydin University, nurtensen@aydin.edu.tr, https://orcid.org/0000-0001-8844-6610 Research Article - Submit Date: 20.10.2020, Acceptance Date: 27.10.2020

DOI: 10.17932/IAU.IJMCL.2015.014/ijmcl_v06i2004 
reflections of multiple personality that appear in the protagonists of City of Glass, The Locked Room and Fight Club. These three works have been chosen in particular because they present a certain way of dealing with paranoia and the multiple personality issue within the scope of Postmodernism. Key words: Postmodernism, Paul Auster, Chuck Palahniuk, City of Glass, The Locked Room, Fight Club, Paranoia, Multiple Identities

\section{ÖZ}

Postmodernizm yirminci yüzyılın ortalarında başlayan ve günümüze kadar devam eden bir akımdır. Teorinin kesin başlangıcını bulmak ya da onu tam olarak tanımlamak zordur. Postmodernizm ile ilgili kesin olabileceğimiz tek şey modernizmden radikal bir şekilde ayrılmasıdır. İnsanların düşünce ve davranış şekillerini değiştirmiştir. Lyotard, The Postmodern Condition: A Report on Knowledge kitabinda "postmodernizm ondokuzuncu yüzyıldan beri bilim, edebiyat ve sanat konusundaki oyunun kurallarını değiştiren dönüşümleri takip ederek, kültürümüzü değiştirmiştir” diye öne sürmektedir. Bu açıdan bakıldığında, postmodernizmin modernizimden nasıl farklılaştı̆̆ net bir şekilde görülmektedir. Anlaşılacağı üzere, modernizmde yüksek ve düşük sanat biçimleri arasında katı sınırlar varken, postmodernizmde bu ikisine eşit ölçüde ağırlık verilmektedir. Modernizme göre, gerçek ve bilgi bilime dayanmaktadır ve gerçeğin kesinliği ve tekilliği vardır. Ancak, postmodernist akımda gerçeğin çoğulluğuyla karşılaşırız. Bu olgunun bizi paranoya dünyasına götürdüğ̈̈ iddia edilebilir. Şöyle ki, postmodernizmle birlikte, düşünce ve algı bir önceki akımdan farklı bir yöne evrilmiştir ve bu oluşum paranoyanın farklı boyutlarda tanımlanmasına yol açmıştır. Postmodern çağdaki düşünce ve gerçeklik üzerine değişimleri göz önüne alarak, bu makalede, City of Glass, The Locked Room ve Fight Club eserlerine dayandırarak, paranoyak unsurları ve çoklu kişilik sorunsalını inceleyeceğim. $\mathrm{Bu}$ eserler özellikle seçilmiştir çünkü bu çalışmalar, postmodernizm ikliminde çoklu kişilik bozukluğu ve paranoya sorunsallarını ele alarak 
ilginç çıkarımlarda bulunmaktadır.

Anahtar Kelimeler: Postmodernizm, Paul Auster, Chuck Palahniuk, City of Glass, The Locked Room, Fight Club, Paranoya, Çoklu Kişilik

\section{INTRODUCTION}

Since there are many forms of Postmodernism, it is quite challenging to make an exact definition of it. Lyotard, who is one of the leading critics of the movement asks the question of "What is Postmodernism?" in his book, The Postmodern Condition (1979). He defines it as the radically shifted status of knowledge and its dissemination. It is likely that postmodernism restrains itself from establishing a single answer. Hassan describes it as "like a ghost which eludes definition" (2003, p3). The more critics try to answer this question, the more complicated its definition becomes. Hassan puts it aptly: "I know less about postmodernism today than I did thirty years ago" (2003, p3).

In spite of all this controversy, it is an undeniable fact that there is a radical break between Postmodernism and Modernism. In this regard, Harvey, in The Condition of Postmodernity, posits the controversy by categorizing Postmodernism: "modernist sentiments may have been undermined, deconstructed, surpassed, or bypassed, but there is little certitude as to the coherence or meaning of the systems of thought that may have replaced them" (1989, p.42).

As well as the changes the postmodernist idea has caused in the perception of truth, belief and knowledge, it opened a door for the applications of new methods in literary works. Postmodern literary works embody various literary devices and techniques. They include fragmentation, parody, paranoia, dark humour, unreliable narrator, authorial self-reference, and so on. In Postmodernism, we also encounter self-reflexivity. It allows authors to create worlds within worlds. "Language constructs immense edifices of symbolic representations that appear to tower over the reality of everyday 
life like gigantic presences from another world" (Mchale, 2003, p130). In this view, Postmodernism rejects traditional forms of writing found in Modernism. This trait of language and form itself constitutes a powerful cause for paranoia of the age.

In the modern epoch, human beings were under the influence of metanarratives. One single truth was assumed to have universal application. As Flieger posits, "for metanarrative is, quite simply, the consensual scheme of things writ large, the theological versions of history that people cherish (such as belief in Progress or Enlightenment) (p 89). One was content that he/she could secure his/her safety in the realm of singularity and certainty of his/ her perception of truth. However, from the perspective of postmodern era, this feeling of certainty has turned upside down. Instead, one encounters the possibility of many truths. "(...) for Lyotard, postmodernism is characterized by "the loss of belief in metanarrative"' (qtd in Flieger, 1997, p89). The idea of plurality forces one to leave his/her comfort zone and take him/ her to the sphere of uncertainties where paranoia is embraced. In the light of this subject, in Seminar III, Lacan defines paranoia as "the question of knowledge, belief and speech" (1993, p36). In this sense, it can be assumed the paranoid postmodern man rejects this perception of truth which is laid in authoritative metanarratives. It can be seen as the rebellion of the individual against the dogmatic perspectives. From this point of view, William Kerrigan and Joseph Smith depict postmodernism as "the embrace of the uncertainties of discourse" (1989, p ix).

The most striking changes facilitated by Postmodernism include the perceptions of truth and reality. Truth is defined as "the property of being in accord with fact or reality" in the dictionary of Merriam-Webster's Online (2020). Even though several dictionary definitions of this concept exist, there have been many debates based on the nature of truth. For instance, Foucault suggests that "each society has its own regime of truth, its "general politics" of truth: that is, the type of discourse which it accepts and makes 
function as true" (qtd in Taylor, p153). Reality, on the other hand, is defined as "something that is neither derivative nor dependent but exists necessarily". Considering these definitions, one can realise truth and reality are different concepts even though they are assumed to be interchangeable.

Truth and reality take many forms in the postmodern world, which allows multiple possibilities of truth. It can even be considered everybody has got their own truth. The concept of plurality of the perceptions of truth and how the postmodern era approaches to this concept is well felt through the Diels' suggestion on truth.

There never was nor will there ever be any man who has certain knowledge about the gods and about all the things that I tell of. And even if he does happen to get most things right, still he himself is not aware of this. Yet, all may have the shadows of the truth. (1906, p64).

Hence, it seems correct to speak of the perception of truth rather than the truth as a singular, unchanging universal concept.

What creates the difference between Modernism and Postmodernism are the fragmentariness of the truth and the multiplicities of the notions of truth and reality. From the perspective of Modernism, the world is considered to be fragmented. Individuals are thought to have schizophrenic personalities. They are so due to the radical changes, which the world underwent after the World War II. They are made alienated as long as they are not able to adapt themselves to the new world order. In other words, they are pushed towards being outsiders. That is how modern man is considered as schizophrenic. In postmodernism, this schizophrenia turns into paranoia. We see split personalities in the modern world. In the Postmodern age, we encounter multiple personalities instead. This phenomenon is said to be caused bysame as the concept of truth- the multiple possibilities of the perception of reality that the postmodernist era offers to human beings.

As relevant to this study on paranoia, Jelena Mandic depicts paranoia as "a symptomatic condition of post modernity" (2014, p143). It can be read as 
post modernity serves a new sort of thought and demeanor type to individuals of the new epoch in order to be able to adapt. In this regard, the case of Dr. Schreber of Freud can be accepted as a good example for the definition of paranoia of Mandic. In Dr Schreber's case, "Freud speculates, paranoia is a defence and a strategy of adaptation" (qtd in Fflieger, 1997, p91). While an epoch changes, the episteme -in Foucauldian words- changes as well. One encounters the challenges of the new upcoming age. No matter how revolutionary the conditions are, one struggles in the flow of the new epoch. $\mathrm{He} /$ she happens to change his/her mindset. This force for change has become more problematic in the postmodern age. As it has been mentioned before in this study, as long as the belief for metanarratives vanishes, one becomes more paranoid. While the paranoid man of the postmodern age fluctuates between possibilities, he/she constitutes a self-defence mechanism to be able to adapt him/herself to the changes that the era offers. The weaker the self -mechanism is, the harder it becomes for the paranoid to adapt and he/ she is very likely to encounter multiple identities problematique.

\section{HOW HUMANITY HAS LOST IT}

Paranoia is a classic trope of Postmodernism. Related to the case, in American Gothic Fiction, Victor and Smith discuss "the postmodern and its populist tendency (...) its embrace of fragmentary and use of paranoia" $(1996, \mathrm{p} 15)$. Jonathan Schell makes a good description of scepticism and paranoia with the statement which says "the world of undiscriminating cynicism, where no one is trusted and nothing is believed, is in many ways a comfortable one." (qtd in Coale, 2019, p1). This paranoia element is reflected in City of Glass, which is a prominent work of Paul Auster.

Many traces of scepticism and paranoia may be encountered in City of Glass. In this sense, the following instance sets a good example. "Much later, when he was able to think about the things that happened to him, he would conclude that nothing was real except chance" (Auster, 2006, p3). 
This sentence above which is taken from the narrative is a strong example for the paranoia of the age. Our protagonist, Daniel Quinn, reaches the conclusion which asserts we cannot be sure about anything. Rather, we can have possibilities and/or illusion of the truth. Therefore, we should merely take into consideration the other numerous possibilities. We should look at the things from different perspectives. "Like Derrida, Michel Foucault has asked us to look at things differently, to shift the level of our analysis out of our traditional disciplinary divisions and into that of discourse" (Hutcheon, 1989, p97).

"As he opened the door that would lead him into the lobby, he gave himself one last word of advice. If all this is really happening, he said, then I must keep my eyes open." (Auster, 2006, p13).

In the other example above cited from the novella, we encounter another trace of doubt. Quinn, sitting at home, receives a phone call. He does not know the person on the line. The man who is on the other side of the line is asking for Paul Auster. He needs Auster's help. Even though Quinn knows that it is a wrong number, he agrees to go and meet that person. When he arrives at the apartment of the stranger, he gives himself a piece of advice. It is a piece of advice for a "just in case" situation since again he is not sure about what is happening there. He is suspicious even about the thing that he is experiencing.

The Locked Room, which is included in New York Trilogy, embodies the numerous elements of paranoia as well. The narration evolves around the disappearance of Fanshawe and our narrator tries to find him. In this view, the story displays similarities with the one in City of Glass and as it is assumed it causes the reader paranoia and suspect as a reader response.

Every life is inexplicable, I kept telling myself. No matter how many facts are told, no matter how many details are given, the essential thing resists telling.....We imagine the real story inside the words, and to do this we substitute ourselves for the person in the story, pretending 
that we can understand him because we understand ourselves. This is a deception (Auster, 2006, p163).

In the quotation cited from The Locked Room above, the reader is taken to the domain of suspicion/doubt. It is obvious that even our narrator is not sure about the reality. He keeps questioning the incidents which he has been experiencing from the beginning. He tries to put the pieces together to see the whole puzzle. Yet, in the end he ends up with different realities. He realizes that even real incidents and true stories can be deceptive. In this regard, this situation reminds us how the Postmodernism approaches to the possible reality and perceptions of truth.

In The Locked Room, Auster serves us a big deal of ambiguity. He puts readers in the sphere of uncertainty successfully. As the narrative proceeds, we, as readers, get to the point where we identify the narrator and Fanshawe as the same person to some extent. We see that the narrator puts himself in Fanshawe's story. With the help of this, he is able to write of Fanshawe. What Auster seems to do here is to blur the reality and confuse the reader. Hence, he can easily increase the curiosity and suspicion of the reader. Another element which keeps reader's curiosity alive throughout both stories of Auster, City of Glass and The Locked Room, is that the author offers the reader open-ended narratives. The last paragraph of the narrative of The Locked Room sets the best example to show the suspicion level which the story creates on readers. "He had answered the question by asking another question, and therefore everything remained open, unfinished, to be started again" (Auster, 2006, p307). This quotation displays how the readers' response is navigated while reading the whole story. Whenever the reader feels like having found an answer, simultaneously it is realised that one is not even close to it. Every question gives birth to another one and each answer creates another question. It is just like a vicious cycle. It perpetuates itself. It does not let the reader obtain a resolution.

As it is the third literary work showcased in this study- which initially seems 
to reflect the same markers but will prove to display same diversion- Fight $C l u b$ is another novel whose narration embraces paranoia from top to bottom. Besides the themes of masculinity, consumerism, identity and religion, it focuses on the concept of reality as well. In the narrative, it is witnessed that the protagonist(s) are in search of the truth and reality. Though, the reflection of this search and the paranoia is quite different than the ones we encounter in City of Glass and The Locked Room.

In Palahniuk's Fight Club, characters are the members of the consumer society. The narrator is also trapped in a consumerist society. This idea of consumption is given to people by the society and endless capitalist commercials. Charmed by the products in the advertisements, postmodern man consumes more and more. In fact, behind these advertisements is the idea of making people believe they really need those products. As long as they buy the products on the advertisements, they are made to believe it is the "real" thing that they need indeed. Zizek proposes that "capital itself functions as a chimeric apparition which, although it can nowhere be spotted as a positive, clearly delimited entity, nonetheless functions as the ultimate Thing governing our lives" (qtd in Paradise, 2012, p30) which can be traced all the way back to Maslow's consumer behaviour theory.

In other words, these products may be related and perceived as the "object petite a" of Lacan. For Lacan, as from the day we are born, all we want is to satisfy our desires. According to the Lacanian approach, our desire is interpreted as finally reaching the Real. Yet, we are aware that we cannot reach it since The Real is unattainable. It can only be experienced through one's "object of desire". It could be a person, a job, or an object that we desire to own. We try to substitute it with that object petit a. It is exactly where one's paranoia starts. Whenever we feel that our object of desire is not attainable, we become paranoid. While swinging among the possibilities, the truth is permanently questioned. This situation increases one's suspicion. This feeling of paranoia is capitalist-made. It has been permanently 
emphasized that the 'capital' organises the social roles and the status of the individual. Jameson in his book of the Logic of Late Capitalism portrays the atmosphere aptly.

It seems to me very important to persuade ourselves ... that we are inside the culture of the market and that the inner dynamic of the culture of consumption is an infernal machine from which one does not escape by the taking of thought (or moralizing positions), an infinite propagation and replication of 'desire' that feeds on itself and has no outside and no fulfilment $[\ldots]$ so that at some outer limit these very gestures of revolt are also those programmed into the system (Jameson, 1991, p206, 209). From the Lacanian point of view, as Jameson also emphasizes, all kinds of material possessions individuals own merely represent the object petit a with no fulfilment. The more they buy, the more they think they have reached the "Real" they have been looking for. Yet, again, as soon as they obtain these materials they realise it is not the reality they have longed for. Thus, this circumstance launches another never-ending search.

I love everything about Tyler Durden, his courage and his smarts. His nerve. Tyler is funny and charming and forceful and independent, and men look up to him and expect him to change their world.

Tyler is capable and free. I am not. I am not Tyler Durden.

"But you are, Tyler" Marla says (Palahniuk, 174).

The dialogue above, which takes place between Jack and Marla makes reader's suspicion increase to the utmost. It can be considered as climax for our paranoia. As of the beginning of the narrative, we suppose Jack and Tyler are friends. As the story progresses, we start to have doubts about our characters. Our mind swings between possibilities. We try to find answers for our questions such as "Are Tyler and Jack different people?" or "Has Jack got schizophrenia and is it Jack's pure alter ego that dominates the whole incidents?" In this regard, related to this study, alter ego and multiple identities concepts are required to be reviewed. In Merriam Webster Dictionary, the 
phrase is defined as "a second self or different version of one self" (2020). Etymologically, borrowed from Latin, the phrase means "second I". In this regard, Freud and his analysis on id, ego and superego become more of an issue. He defines ego as a "coherent organizations of mental process" (1923, p17). It is not a single device which operates basically. Rather it is a sophisticated entity. However, as it is implied in the definition, these constitutions are compatible. They process in harmony. Many have been suggested and discussed upon the development process of this organization. In his "On Narcissism: An Introduction" (1914), Freud postulates that "the ego cannot exist in the individual from the start; the ego has to be developed" (qtd in Russell, p353). As it is implied in the quotation, the development of the ego is a process and it does not remain the same as it first appears on an individual. This process can be related to concepts of Ideal-ego and Egoideal of Lacan. Regarding the narrative of Fight Club, it can be seen how Jack's ego evolves and his alter ego is shaped and triggered by consumerist society. It can also be observed how paranoid the protagonist becomes due to the alterations that society causes to occur on his ego.

\section{WHICH ONE OF YOU IS SPEAKING}

Another problematic of the postmodern era is multiple identities. It may be suggested that it is caused by the paranoia issue that has been uttered above. "Discussions of postmodernism seem more prone than most to confusing self-contradictions, again perhaps because of the paradoxical nature of the subject itself" (Hutcheon, 1989, p5). What Hutcheon proposes may be assumed as the fragile state of the self which is inclined to fracture in the postmodern world. Related to this study of multiple identities, multiple personality disorder becomes an issue. Known as Dissociative Identity Disorder at present, it is defined as "a cross-cultural, developmental, posttraumatic disorder whereby a traumatized child with an inborn capacity to dissociate avoids being overwhelmed diminished by severe, chronic abuse 
by dissociatively compartmentalizing feelings, memories, ways of thinking and talents into different self-parts (qtd in Harvey \& Josselson, 2012, p4). However, in this study, multiple identities issue is not been showcased as a psychotic disorder. Rather, it is displayed as a postmodern human condition. Human beings may have a different personality when they are alone, when they are at work, and have a different one in their social life. This should not be confused with a psychotic disorder mentioned above but is thought to be a natural condition. What is meant to be proposed is that we never know which personality we embody is the real one. Alphonse Karr states that "all people have three characters that which they exhibit that which they are and that which they think they are" (2020). In other words, we are neither able to certain of the truth nor our real identities.

This is another problematic which the dynamics of the postmodern era tries to impose to postmodern man. This new age seems to bring out a new way of thought patterns. It deconstructs the teachings of grand narratives.

$[\ldots]$ we lose the grand narratives that once bound us together (with ourselves and with others) ; to compensate for that loss, we are given cultural paranoia, which binds us to structures/concepts with which we can identify, such as nation, class, gender, and the "human" (qtd in Elias, 289).

Considering what Mark Siegel proposes, it may be said modern man becomes more paranoid than ever in history as he does not own a basis to base his perception of truth. Thus, he begins to invent different ways to identify himself, which is enabled by imposed cultural and capitalist applications as Elias posits aptly, "that paranoia is culturally produced for us" (2003, p289). From literally perspective, the concept of multiple identities issue is examined as a natural condition of self in the postmodern world rather than a disorder in three literary works of City of Glass, The Locked Room and Fight Club. As being the first work to be studied, in City of Glass, the reader witnesses the reflection of multiple identities problematic. The protagonist exists with 
the name of Daniel Quinn. There is Peter Stillman, who asks for Quinn's help for his father's case. We have Boston Stillman, who is the father of Peter. Max is another character in the narrative, of whom Quinn is very fond of. William is the pseudonym used by Daniel Quinn for years when he writes his stories. At last but not the least, there is Paul Auster who is supposed to be a private agent and that who Quinn thinks he is himself. Reading the narrative, reader's mind fluctuates among possibilities. He/she experiences confusion as the certainty is blurred and this yields paranoia.

As he wandered through the station, he reminded himself of who he was supposed to be. The effect of being Paul Auster, he had begun to learn, was not altogether unpleasant. Although he still had the same body, the same mind, the same thoughts, he felt as though he had somehow been taken out of himself, as if he no longer had to walk around with the burden of his own consciousness (...) to be Auster meant being a man with no interior, a man with no thoughts" (Auster, 2004, p50).

The example above from the narrative constitutes very good example of multiple personality issue which is aimed to study in this work. At first glance, it may be assumed that the protagonist is aware Paul Auster does not exist. However, as his inner thoughts compile, he finds himself in a different dimension in which he has made himself believe to be Paul Auster. Meanwhile, the uncertainty our protagonist is experiencing causes suspicion for the reader as well and it puts the reader in the domain of paranoia, which is aimed to achieve as reader's response.

Likewise, in Fight Club the same concept of multiple identities issue is involved. It has a twist in the ending just like in City of Glass. It turns out that the Narrator and Tyler Durden are the same person. They together represent the split person: Jack. The Narrator has a weak personality, weak body and a routine life shaped by capitalism. On the other hand, Tyler is the alter-ego of Jack, who is much stronger, well-built and popular among women. Jack dreams for being like the man in his thoughts. He desires to 
be like Tyler. He desires to be accepted by the authority.

This idea reminds us what Freud asserts about the unconscious. As he puts forward it, we all have unconscious where we keep all our real desires and urges which push their way to the surface, namely, our consciousness. Many studies and research exist on the unconscious. However, whenever the philosophers have reached the conclusion and made up their minds about the phenomenon, they have been stuck in another problem. Is that their conscious or unconscious mind which has led them to the conclusion? The result itself perpetuates another question. As Freud posits,

It is true that philosophy has repeatedly dealt with the problem of the unconscious, but with few exceptions, philosophers have taken up one or other of the two following positions. Either the unconscious has been something mystical, something intangible and indemonstrable, whose relation to the mind has remained obscure, or they have identified the mental with the conscious and have proceeded to infer from this definition that what is unconscious cannot be mental or a subject for psychology. These opinions must be put down to the fact that philosophers have formed their judgment on the unconscious without being acquainted with the phenomena of unconscious mental activity, and therefore without any suspicion of how far unconscious phenomena resemble conscious ones or of the respects in which they differ from them (qtd in Tauber, 2010, p54).

What our Narrator is experiencing represents the incident, which Freud proposes about unconscious. In the narrative, when Jack is asleep, Tyler- the unconscious part of his mind- gets the whole control of his life. Many examples of this exist in the narrative. The instances include Jack's exploding his own flat, having sex with Marla, joining the Fight Club and so on. Considering Freud's assertion on unconscious mind, it can be assumed that Jack does not do them with his own awake intentions. It is all caused by his unconscious mind, his alter-ego. Hence, these examples in the narrative display the 
reality that all human beings might own various characters and identities. There is Marla, and she is in the middle of everything and doesn't know it. And she loves you.

She loves Tyler.

She doesn't know the difference.

Somebody has to tell her. Get out. Get out. Get out (Palahniuk, 2005, p144).

In the quotation above, the identity issue, which the Narrator experiences, is explicitly witnessed. It can be seen how paranoid he becomes trying to find his real identity. When his thoughts are streaming, he fights against them. He fights against his alter ego, which is actually the other side of him. As a paranoid, he portrays himself in imaginary occurrences and personalities. This occurrence might be related to how Lacan describes paranoids: "the paranoiac imagines him/herself in the place of the Other (Other is the Thing which is unattainable), and thus sees an alternative version to reality" (qtd in Nicol, 1999, p46).

Moreover, in the narrative numerous symbols which may be assumed as the traces of multiple personalities issue are encountered. The scars, for instance, may be accounted to represent the duality and also secret identities that characters have. Named as Tyler's kiss, the burn scar that Narrator has indicates that Jack is the follower of Tyler. As another example, the bite mark on his cheek represents Jack's identity as a member of Fight Club. Those marks can only be seen by our Narrator not by the other people around him. From this stance, it may be inferred that this incident does not only display Jack's alter ego, it also leads the reader to the sphere of paranoia that was uttered in the earlier section of this study.

The Locked Room is another domain where the reader gets into paranoia and multiple identities. It may be suggested that Paul Auster causes this situation intentionally. He tortures reader's psychology by creating narratives within narratives. He aims to show that there is not only one reality and there is 
not only one you, which is quite a postmodernist treat.

In the novella, we see the narrator's obsession with Fanshawe's story. His obsession is so strong that he almost loses himself while he is searching for his friend. The reader can easily tell that he loses his true self. He even pictures himself as Fanshawe. It may be assumed that he finds himself in a different identity. What is more, he cannot realise this incident until Fanshawe's wife warns him and tells him that they may need to consider him dead. Not until then, had he turned to his true self.

We exist for ourselves, perhaps, and at times we even have a glimmer of who we are, but in the end we can never be sure, and as our lives go on, we become more and more opaque to ourselves, more and more aware of our own incoherence (Auster, 2006, 243).

The quotation above from the novella may be considered as another example which displays how alter ego works. It can also constitute a good example to show the process between Ideal-ego and Ego-Ideal. Lacan divides human psyche into three forms and he proposes that the ideal-ego is constructed at the mirror stage when the infant imagines him/herself as a perfect whole. Yet, later on he/she realizes that it is only a misconception since he/ she is not as perfect as he/she has imagined. Hence, when his/her Ego-Ideal appears, this individual begins to do what it takes in order to appear like he/she has imagined and desired. It initiates to be formed when one starts to look at $\mathrm{him} /$ herself from a rational perspective. It may be said that one requires to create another self. As Auster (2006) proposes in the quotation, as long as one's awareness increases, the lack may be seen in detail.

"And death...happens to us every day" (2006). This statement which is located on the cover page of the novella probably displays the chaos about multiplicity of identities. Death is the end of physical life. When it comes, our stories finish. Yet, I believe in this statement, Auster refers to death as the end of one of our personalities. Very next day, another of you is born. When we consider the timeline being circular in the 
postmodern age, we cannot have linear lives. "Rather, Plato visualized time as curving back on itself- as circular in nature" (Nahin, 2001, p104). As it may be inferred from what Plato proposes, it is not about starting from one point and finishing the line on the other side. As life progresses, our personalities are likely to change as well.

\section{CONCLUSION}

Even though there have been many attempts to define postmodernism, critics and theorists have failed in finding a precise answer to the question. Whatever the outcomes of attempts are, there is a common point they share: postmodernist movement privileges plurality rather than singularity of the truth unlike modernism and there is an inclination for desertion of traditional styles. In this respect, postmodernism is more than a movement. Rather, it may be regarded as a new perspective.

The notions of paranoia and multiple identities have been projected through literary works. They represent the different dimensions of reality and appear as the hallmarks of the postmodernist literature. Hence, as Brennan proposes, the postmodern age is "the age of paranoia" (1991, p20). The paranoid anxieties of post dramatis personae of the postmodernist movement are also reflected in many disciplines and in flow of daily life. In this stance, it may be seen that individuals and literary figures feel discontent with the circumstances they are experiencing and the places where they are. Moreover, the distrust one feels is not confined to the places or objects which he or she is exposed to. Same individual is likely to have the feeling of paranoia towards his or her identity as well. In other words, one becomes inclined to create self-made identities.

Throughout this study, the concepts of paranoia and multiple identities in City of Glass, The Locked Room and Fight Club have been examined and it has been concluded that these three leading works of literature explore 
paranoia and multiple identities. They propose readers a sphere in which the postmodern individual long for the truth and battles with paranoia while searching for it.

\section{REFERENCES}

Alphonse Karr Quotes. (n.d.). allauthor.com. Retrieved September 16, 2020, from allauthor.com Web site: https://allauthor.com/quote/181028/ Auster, P. (2006). The New York Trilogy (Vol. 4). Penguin Classics. Best, S. (1992). Creative paranoia: a postmodern aesthetic of cognitive mapping in" gravity's rainbow. The Centennial Review, 36(1), 59-87. Brennan, T. (1991). The age of paranoia. Paragraph, 14(1), 20-45.

Coale, S. C. (2019). Paradigms of Paranoia: The Culture of Conspiracy in Contemporary American Fiction. University of Alabama Press.

Elias, A. (2003). Paranoia, theology, and inductive style. Soundings: An Interdisciplinary Journal, 86(3/4), 281-313. Retrieved August 24, 2020, from http://www.jstor.org/stable/41179113

Harvey, D. (1989). The condition of postmodernity (Vol. 14). Oxford: Blackwell.

Hassan, I. (2003). Beyond postmodernism. Angelaki: Journal of Theoretical Humanities, 8(1), 3-11.

Hutcheon, L. (1989). Historiographic Metafiction Parody and the Intertextuality of History. Johns Hopkins University.

Jameson, F. (1991). Postmodernism, or, The Cultural Logic of Late Capitalism. Duke University Press.

Lacan, J. (1993). The Seminar. Book III. The Psychoses, 1955-56. Trans. Russell Grigg. London: Routledge, 268.

Lyotard, F. (1979).The Postmodern Condition: A Report on Knowledge (Manchester: Manchester University Press).

Mandić, J. Ž. (2014). Fear and Paranoia as a Postmodern Condition in Thomas Pynchon's "The Crying of Lot 49" and David Lynch's "Blue 
Velvet". Филолог-часопис за језик, книжевност и културу, (10), 143-151. McHale, B. (2003). Postmodernist fiction. Routledge.

Nahin, Paul J. (2001). Time machines: Time travel in physics, metaphysics, and science fiction. Springer Science \& Business Media.

Nicol, B. J. (1999). Reading paranoia: paranoia, epistemophilia, and the postmodern crisis of interpretation. Literature and Psychology: A quarterly journal of literary criticism as informed by depth psychology, 45(1\&2). Palahniuk, C. (2005). Fight Club: a novel. WW Norton \& Company. Paradis, K. (2012). Sex, paranoia, and modern masculinity. SUNY Press. Sage, V., \& Smith,A. L. (Eds.). (1996). Modern Gothic: A Reader. Manchester University Press.

Smith, J. H., \& Kerrigan, W. (1989). Taking Chances: Derrida, Psychoanalysis, and Literature.

Tauber, A. (2010). Distinguishing Reasons and Causes. In Freud, the Reluctant Philosopher (pp. 54-84). Princeton; oxford: Princeton University Press. doi:10.2307/j.ctt7rrpr.7

Taylor, C. (1984). Foucault on Freedom and Truth. Political Theory, 12(2), 152-183. Retrieved September 30, 2020, from http://www.jstor.org/ stable/191359 